\title{
Long Noncoding RNAs in Development and Regeneration of the Neural Lineage
}

\author{
Hadas Hezroni, Rotem Ben Tov Perry, and Igor Ulitsky \\ Department of Biological Regulation, Weizmann Institute of Science, Rehovot 76100, Israel \\ Correspondence: igor.ulitsky@weizmann.ac.il
}

\begin{abstract}
Long noncoding RNAs (IncRNAs) are gathering increasing attention toward their roles in different biological systems. In mammals, the richest repertoires of lncRNAs are expressed in the brain and in the testis, and the diversity of lncRNAs in the nervous system is thought to be related to the diversity and the complexity of its cell types. Supporting this notion, many IncRNAs are differentially expressed between different regions of the brain or in particular cell types, and many lncRNAs are dynamically expressed during embryonic or postnatal neurogenesis. Less is known about the functions of these genes, if any, but they are increasingly implicated in diverse processes in health and disease. Here, we review the current knowledge about the roles and importance of lncRNAs in the central and peripheral nervous systems and discuss the specific niches within gene regulatory networks that might be preferentially occupied by lncRNAs.
\end{abstract}

Tens of thousands of loci in mammalian genomes produce long noncoding RNAs (lncRNAs), which are generally less abundant (by roughly an order of magnitude) and much more tissue-specific than protein-coding genes. A typical mammalian cell type expresses (at one transcript per cell, on average) at least $\sim 50 \%$ of all protein-coding genes, but only approximately 1000 distinct lncRNAs ( $<5 \%$ of the currently annotated lncRNAs). Most lncRNAs are produced from regions distal to other genes, but some, enriched with the more highly and broadly expressed ones, are produced in close proximity to promoters of other genes (most commonly in a divergent orientation) or from other "genic" regions. Another subset of lncRNAs, which is also rather abundant, serves as precursors for small RNAs, such as microRNAs and small nucleolar RNAs (snoRNAs), and the interplay between the two classes has been reviewed elsewhere (Ulitsky 2018).

Most IncRNAs are spliced, and produce "linear" isoforms that start with a cap and end with a poly(A) tail, which help stabilize the RNA, but there is an increasing appreciation of the diversity of circular RNAs (circRNAs), which are lncRNAs produced by backsplicing (Ebbesen et al. 2016). We will focus here only on linear RNA forms, as functions of the circular forms in the neural system were recently reviewed (Sekar and Liang 2019).

Studies describing where lncRNAs are expressed, utilizing techniques used to measure mRNA expression, have overall progressed rapidly. There is also an increasing number of reports on what lncRNAs do in the nervous system, described below. It is overall much less clear how lncRNAs function, but various mechanisms have been proposed for both cis and trans actions. Overall, there are no reasons to think that the mechanisms utilized by IncRNAs in the nervous system are different than those used in other tissues, but there are so far few similarities between mechanisms proposed for different lncRNAs (for a recent review, see Kopp and Mendell 2018), and so transfer of mechanistic understanding from one gene to others remains difficult.

There are several reasons to be interested in what lncRNAs do specifically in the nervous system. One is that the brain expresses a particularly rich repertoire of lncRNAs, rivaled only by that expressed in germ cells. Together with the rich cell type diversity of the nervous system, it is possible that lncRNAs often regulate cell fate decisions in the brain, and so neuronal systems can be particularly appealing for dissecting such functions. Another reason is the common diseases that affect the brain, and in which lncRNAs are commonly dysregulated (see below). From this perspective, lncRNAs can act as interesting biomarkers, potential therapeutic targets, or even potential therapeutic agents (although delivery of large RNAs remains a formidable challenge). As biomarkers, lncRNAs can be particularly appealing because of their tissue specificity, although the low abundance of the vast majority of lncRNAs will likely make it difficult to robustly detect them in distal tissues (e.g., detect in the blood lncRNAs arising from neural cells in the brain).

\section{DIFFERENTIAL EXPRESSION OF IncRNAs IN THE BRAIN AND DURING NEURAL DIFFERENTIATION}

Several large-scale resources of gene expression are now available and describe where lncRNAs are expressed at various resolutions (Table 1). Both human and mouse brains express a relatively rich repertoire of lncRNAs (Ravasi et al. 2006; Cabili et al. 2011; Derrien et al. 2012), many of which display unique temporal and spatial expression patterns within the central nervous system

(C) 2019 Hezroni et al. This article is distributed under the terms of the Creative Commons Attribution License, which permits unrestricted reuse and redistribution provided that the original author and source are credited. 
Table 1. Large-scale resources of long noncoding RNA (lncRNA) expression in the nervous system

\begin{tabular}{|c|c|c|c|c|}
\hline Name & URL & Tissues & Methdology & lncRNA annotations \\
\hline GTEx & $\begin{array}{l}\text { https://gtexportal.org/ } \\
\text { home/index.html }\end{array}$ & $\begin{array}{l}54 \text { human tissues, including } 13 \\
\text { brain regions }\end{array}$ & RNA-seq & GENCODE/Ensebml \\
\hline Allen brain atlas & $\begin{array}{l}\text { https://portal.brain- } \\
\text { map.org/ }\end{array}$ & Various & $\begin{array}{l}\text { RNA-seq, single-cell RNA- } \\
\text { seq, and FISH in human and } \\
\text { mouse fetal and adult brain }\end{array}$ & RefSeq \\
\hline $\begin{array}{l}\text { EBI expression } \\
\text { atlas }\end{array}$ & $\begin{array}{l}\text { https://www.ebi.ac.uk/ } \\
\text { gxa/home }\end{array}$ & $\begin{array}{l}\text { Various studies, including } \\
\text { atlases of tissues and cell lines } \\
\text { and differential expression }\end{array}$ & RNA-seq & GENCODE/Ensembl \\
\hline ENCODE & $\begin{array}{l}\text { https://www } \\
\text {.encodeproject.org/ }\end{array}$ & $\begin{array}{l}\text { Mouse tissues (mostly adult) and } \\
\text { human and mouse cell lines }\end{array}$ & RNA-seq & GENCODE \\
\hline Eurexpress & $\begin{array}{l}\text { http://www.eurexpress } \\
\text {.org/ee/ }\end{array}$ & Mouse in situ images & FISH & $\begin{array}{l}\text { Various (mapped to } \\
\text { FISH probes) }\end{array}$ \\
\hline $\begin{array}{l}\text { Kaessmann } \\
\text { laboratory Evo- } \\
\text { Devo resource }\end{array}$ & $\begin{array}{l}\text { https://apps } \\
\text {.kaessmannlab.org/ } \\
\text { lncRNA_app/ }\end{array}$ & $\begin{array}{l}\text { Developmental time course in } 7 \\
\text { tissues in } 7 \text { species }\end{array}$ & RNA-seq & $\begin{array}{l}\text { De novo } \\
\text { reconstruction based } \\
\text { on RNA-seq data }\end{array}$ \\
\hline
\end{tabular}

(CNS) and during neuronal and glial cell differentiation (Mercer et al. 2008, 2010; Ramos et al. 2013; Goff et al. 2015). The genome-wide expression patterns of mouse lncRNAs have been studied in cells isolated from different brain tissues, in neural stem cells (NSCs) isolated from the subventricular zone (SVZ) and differentiated in vitro for four days, and in embryonic stem cells (ESCs) differentiated into neural progenitor cells (NPCs) (Ramos et al. 2013). Cells in different regions of the brain, as well as cells at different stages of differentiation, had distinct lncRNA expression patterns. Mean expression specificity score in these data sets was 0.57 for IncRNAs compared to 0.45 for mRNAs, demonstrating that lncRNAs exhibit greater brain region and temporal specificity than mRNAs (Ramos et al. 2013). Another study generated a map of expression dynamics and regulatory effects of $13 \mathrm{lncRNA}$ loci in mouse brain, using mouse models where the lncRNA locus was replaced with a LacZ cassette, and found dynamic and broad expression profiles in the brain, with some lncRNAs presenting highly restricted expression in few brain regions (Goff et al. 2015). These data suggest that some lncRNAs have the potential to carry out specific functions in different types of neural cells and during different stages of acquisition of a neuronal cell identity.

\section{SUBCELLULAR EXPRESSION OF InCRNAS}

The complex morphology of cells in the nervous system opens the question of where within the neuronal cells IncRNAs preferentially reside and act. For individual lncRNAs this is typically addressed using fluorescence in situ hybridization (FISH), recently with single-molecule approaches, which found highly variable localization patterns for lncRNAs, ranging from a single focal region in the nucleus to mRNA-like distribution in the cytoplasm (Cabili et al. 2015). More systematically, physical fractionation of cells followed by high-throughput sequencing can be used to quantify subcellular localization of all transcripts (Sterne-Weiler et al. 2013). In neurons, it is of particular interest to ask whether some lncRNAs transit to the neurites, axons, or dendrites, as there they can have unique and specific functions in neuronal pathways. Using mouse ESC (mESC)-derived neurons and RNA-seq on neurite and soma fractions, the Chekulaeva laboratory recently found that 12 of the 550 tested lncRNAs were at least twofold enriched in neurites (Zappulo et al. 2017) ( $\sim 2 \%$ compared to $\sim 7 \%$ of mRNAs using similar criteria), suggesting that at least in this cell type, a modest fraction of lncRNAs travels to neurites. Additional studies identified specific lncRNAs in axonal fractions (Briese et al. 2016) or sequenced RNA from axons or dendrites but did not specifically describe lncRNAs (Minis et al. 2014; Nijssen et al. 2018; Farris et al. 2019). IncRNAcentric analysis of these and new data will likely shed light on how prevalent are lncRNAs in neuronal processes.

\section{METHODS FOR STUDYING IncRNA FUNCTIONS IN THE NERVOUS SYSTEM}

Whereas the approaches described above are useful for describing where lncRNAs may act, understanding the functions of lncRNAs requires perturbations, which are generally difficult in the nervous system. Challenges include cell accessibility, the postmitotic state of most relevant cells, and the related transfection difficulties. When considering lncRNAs, these constraints meet additional ones, derived from low and sometimes nuclear-enriched expression of most lncRNAs, and their common overlap with other functional elements, such as other genes or enhancers. These difficulties can be addressed by an increasingly diverse toolbox that now contains many modalities that are used in IncRNA research (Fig. 1). These can be broadly divided into genome-editing approaches, which nowadays rely almost exclusively on CRISPRCas9 and which are typically applied in either mouse zygotes (for generating transgenic animals) or mESCs (for either generating transgenic animals or deriving cellular models that can then be differentiated to neuronal cells). In principle, it is also possible to edit the genomes of neuronal cell lines, but the typically large and variable number of chromosomes in these cells make it difficult to obtain homozygously edited cells. Genome editing has obvious advantages in its capability to completely ablate 
A

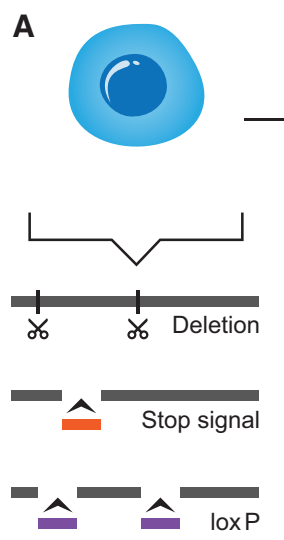

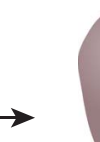
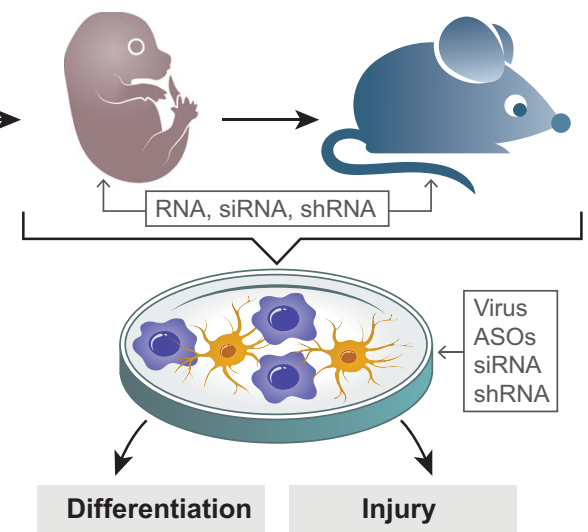
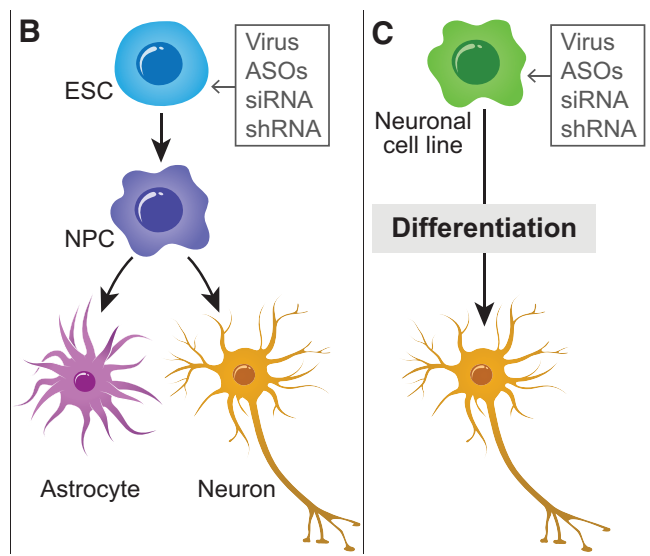

Figure 1. Methods for the study of long noncoding RNAs (lncRNAs). (A) Transgenic animals can be generated using introduction of genome engineering reagents into pluripotent stem cells, mouse zygotes, or early embryos, to induce deletions of lncRNA loci or parts thereof, and insertion of various "stop" signals or insertion of loxP sites that can be used for conditional manipulations. The resulting cells can then be used to derive and breed animal models. The indicated reagents can then be introduced into wild type (WT) or transgenic animals in the embryonic (e.g., using electroporation) or adult stages. Primary cells can be derived from embryonic or adult neural tissues and used in culture, when the indicated methods of manipulation are available and can be applied prior to differentiation of the cells into more mature populations or in vitro injury models. $(B)$ Embryonic stem cells (ESCs) can be manipulated using the engineering methods described in $A$ or by introducing the indicated reagents, and then differentiated into neural progenitor cells (NPCs) and then glial or neuronal cells. $(C)$ Neuronal cell lines, such as Neuro2a/N2a, can be transfected with various reagents and then differentiated into postmitotic neuronal cells. (siRNA) Small interfering RNA, (shRNA) short hairpin RNA, (ASOs) antisense oligonucleotides.

loci and the resulting uniform cellular population. However, several caveats have to be considered. First, as lncRNA loci may overlap other elements, pinpointing phenotypes resulting specifically from lncRNA loss has to typically rely on complementary evidence from other methods (Bassett et al. 2014; Kopp and Mendell 2018). Some editing approaches, like introduction of polyadenylation sequences, are considered relatively "safe" as they do not delete any DNA sequences, but recent discrepancies between the results obtained after editing the Hand2as locus hint that even this approach should be interpreted with caution (Anderson et al. 2016; Han et al. 2019). Promoter deletions are commonly used for lncRNA inactivation and provide a useful compromise between deletion of a relatively short stretch of DNA (compared to whole locus deletion) while having reasonable likelihood to eliminate transcription, although activation of cryptic promoters is often observed (Lavalou et al. 2019).

Another caveat is that successful elimination of lncRNA production still makes it difficult to distinguish between the function of the RNA product and the act of its transcription (Kopp and Mendell 2018). The recent description of introduction loci of self-cleaving ribozymes into lncRNA loci is an exciting progress in this direction (Tuck et al. 2018), but the efficiency of these elements in reducing gene expression is variable, and it is not yet clear how fast the cleavage occurs. Because of that, it is not yet clear if self-cleaving ribozymes may also affect transcription elongation.

The last major caveat is mostly relevant to editing done in cultured cells and, in particular, in pluripotent stem cells. The act of genome editing and, in particular, the double-strand breaks that it usually involves can trigger a stress response that may have lasting effects on the cells and on their ability to later differentiate into different lineages. The general process of establishing stable clones, which typically requires disruptive actions such as cell dissociation and several passages, can also have lasting effects. As a result of these, any edited clone will differ from the original cells and from other clones in ways that may or may not relate to the genetic changes that were acquired. Analysis of multiple independently established clones, as well as of control clones that experienced a very similar procedure (ideally, editing in a bystander locus), can help alleviate these concerns, but this remains very laborious and is still not routinely performed.

Transient introduction of perturbation reagents, such as siRNAs or antisense oligos, typically does not suffer from these caveats but is associated with many other concerns. These perturbations may not lower expression levels below those required for function, may lead to off-target effects (which are well-understood for RNAi, but almost entirely unexplored for antisense oligonucleotides [ASOs] or GapmeRs), and the introduction of the reagents via transfection or infection may activate a stress response. Because of these concerns, it is essential to deploy and compare different combinations of perturbation techniques, which often include genome editing and transient perturbations, ideally using the same system and the same phenotypic assays, although it is not always possible, in particular given the challenges involved in working with neuronal cells.

\section{FUNCTIONS OF InCRNAS IN DEVELOPMENT OF THE NERVOUS SYSTEM}

Different in vivo and in vitro models have been used to study the functions of IncRNAs during neuronal differen- 
tiation and during nervous system development (Table 2). The roles of Cyrano and Megamind, two deeply conserved IncRNAs, were studied during the development of zebrafish embryos by injection of morpholino (MO) antisense oligos, which led to severe defects in brain development (Ulitsky et al. 2011), which were not observed in genetic models later generated for these lncRNAs (Goudarzi et al. 2019; Kok et al. 2015). The function and mode of function of Cyrano was also studied by the generation of knockout (KO) mice (Kleaveland et al. 2018). Loss of Cyrano did not result in any detectable effects on survival, appearance or behavior in mice, but it led to the accumulation of miR-7 and down-regulation of Cdrlas, a circRNA known to regulate neuronal activity (Piwecka et al. 2017; Kleaveland et al. 2018). The function of Megamind (also known as Tunar) was also studied during neuronal differentiation of mESCs. In that system, Megamind knockdown (KD) with shRNAs reduced the differentiation efficiency, demonstrating its potentially conserved role in the acquisition of neuronal cell fate (Lin et al. 2014).

Several studies found roles for lncRNAs during mouse brain development. KO of $E v f 2$, which is transcribed from the Dlx-5/6 ultraconserved region (Feng et al. 2006; Bond et al. 2009), led to reduced numbers of GABAergic interneurons in early postnatal hippocampus and dentate gyrus (Bond et al. 2009). Pantr2 (linc-Brn1b) KO mice have defects in the proliferation of cortical progenitors in the subventricular zone (SVZ) during development (Sauvageau et al. 2013). In addition to the generation of mouse models, NSCs can be isolated from embryonic, postnatal, or adult mice and used for targeting different lncRNAs, optionally followed by in vitro differentiation. Pnky was studied in the mouse cortex using different methods: electroporation of shRNAs to ventricular zone stem cells during development, infection of shRNAs to cultured NSCs from postnatal mouse brain (Ramos et al. 2015), and generation of conditional KO mice (Andersen et al. 2019), which showed that Pnky interacts with PTBP1 splicing factor and acts in trans to regulate proliferation of NSCs and neurogenesis. In vitro differentiation of mouse embryonic NSCs was used to study the function of $\operatorname{lnc}-O P C$. KD of this lncRNA using shRNAs during differentiation of NSCs to oligodendrocyte progenitor cells (OPCs) significantly repressed OPC markers (Dong et al. 2015). Overall these studies have shown that lncRNAs can modulate progenitor proliferation and differentiation and have profound effects on brain development. IncRNAs are also involved in developmental processes in the postnatal nervous system, such as myelination, retinal development, and neuronal outgrowth. The function of four lncRNAs highly expressed in oligodendrocyte lineage cells, lncOL1-4, was studied by siRNA transfection during oligodendrocyte differentiation of primary postnatal OPCs. KD of each of these lncRNAs repressed myelin genes (He et al. 2017). IncOL1 was further studied in KO mice, in which severe defects in myelination were observed at P9 and postnatal week 3 (He et al. 2017). During retinal development, Six3OS is transcribed from an independent promoter separated by $\sim 4 \mathrm{~kb}$ from the promoter of Six3. Six3OS was studied by overexpression or KD with shRNAs in P0.5 mouse retina and was found to be involved in retinal cell specification by binding factors known to co-regulate target genes with SIX3 and potentially recruiting histonemodifying enzymes to SIX3 targets (Rapicavoli et al. 2011). KD of Six3OS in adult SVZ NSCs during differentiation reduced neurogenesis, suggesting that, in addition to its role in retinal development, this lncRNA has roles also in neuronal differentiation (Ramos et al. 2013). Another lncRNA, $B D N F-A S$, which was studied both by transfection of siRNAs or ASOs to neurospheres and by intracerebroventricular delivery of ASOs to adult mice was found to regulate neuronal outgrowth and differentiation both in vitro and in vivo (Modarresi et al. 2012).

Other studies focused on in vitro neuronal differentiation of ESCs or neuroblastoma cell lines, which allow the interrogation of several lncRNAs in parallel. ESCs can be differentiated into NPCs and further into different types of neurons and glial cells, and in recent years, they have been used to identify and characterize the functions of lncRNAs in this process. RMST and three additional lncRNAs have been identified in a study based on neuronal differentiation of human ESCs (hESCs) (Ng et al. 2012), which also found that their KD with siRNAs blocked neurogenesis. A later study found that RMST interacts with SOX2 and promotes SOX2 binding to its target sites in the genome during neuronal differentiation ( $\mathrm{Ng}$ et al. 2013). In haploid mESCs, the overexpression and genetic perturbation of lnc-Nr2fl led to dysregulation of hundreds of genes as the cells were differentiated into neurons, with down-regulated genes related to neuronal pathfinding and axon guidance (Ang et al. 2019). Conversely, overexpression of $l n c-N r 2 f l$ during ESC differentiation and during reprogramming of mouse embryonic fibroblasts (MEFs) to induced neurons (iNs) led to increased neurite length and increased neural conversion (Ang et al. 2019). Another study focused on the differentiation of mESCs to motor neurons (MNs) (Yen et al. 2018). Differentiated MNs were enriched with Dlk-Dio3 locus-derived lncRNAs including Meg3. The depletion of $M e g 3$ resulted in dysregulation of progenitor and caudal Hox genes (Yen et al. 2018).

Neuroblastoma cell lines are another in vitro model of neuronal cells that are generally more accessible to perturbations compared to primary cells. These cells, including the commonly used mouse Neuro2a/N2a and human SHSY5Y cell lines, express many neuronal markers, and when exposed to specific neurotrophic factors, they further differentiate, exit the cell cycle, and extend neurites. Paupar, which is transcribed from a locus upstream of Pax6, was studied in N2a cells by transfection of shRNAs and was found to act both in cis, by regulating Pax6 expression, and in trans, by binding and regulating Pax6 activity, affecting cell cycle progression and neural differentiation (Vance et al. 2014). A later study found that Paupar binds the KAP1 chromatin regulator and promotes KAP1 occupancy to Pax6 targets (Pavlaki et al. 2018). Interestingly, in pancreatic $\alpha$ cells Paupar appears to regulate splicing and not expression of Pax6 (Singer et al. 2019). Dali, also studied with shRNAs in N2a cells, was reported to locally regulate the transcription of the Pou $3 f 3$ 


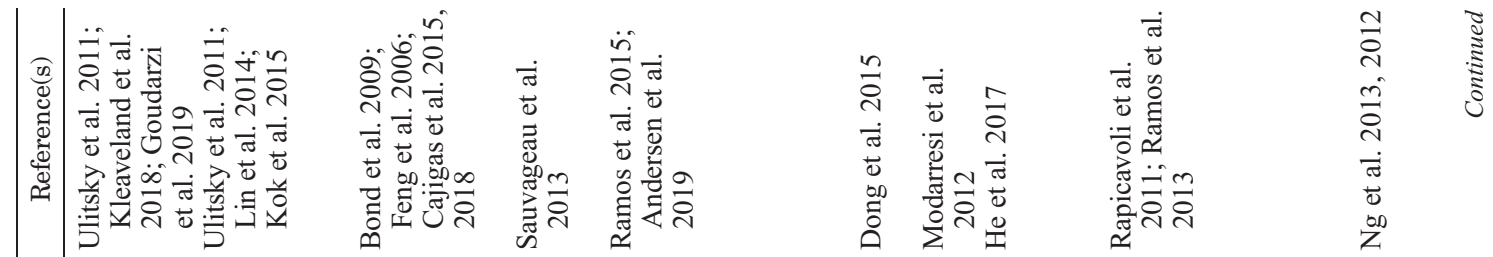

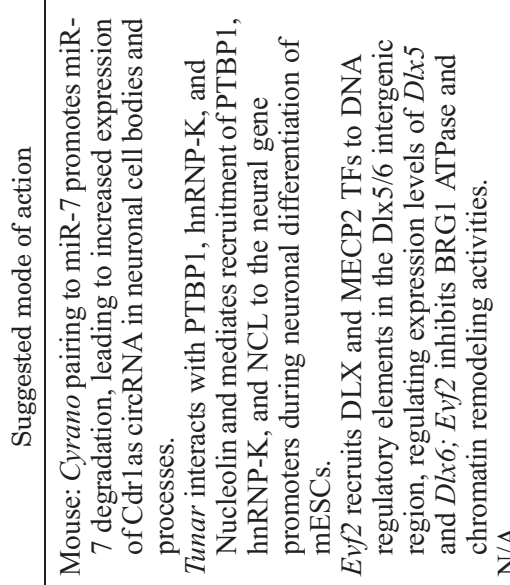

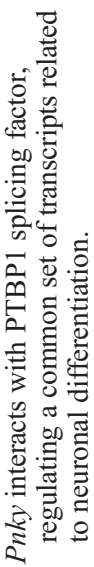
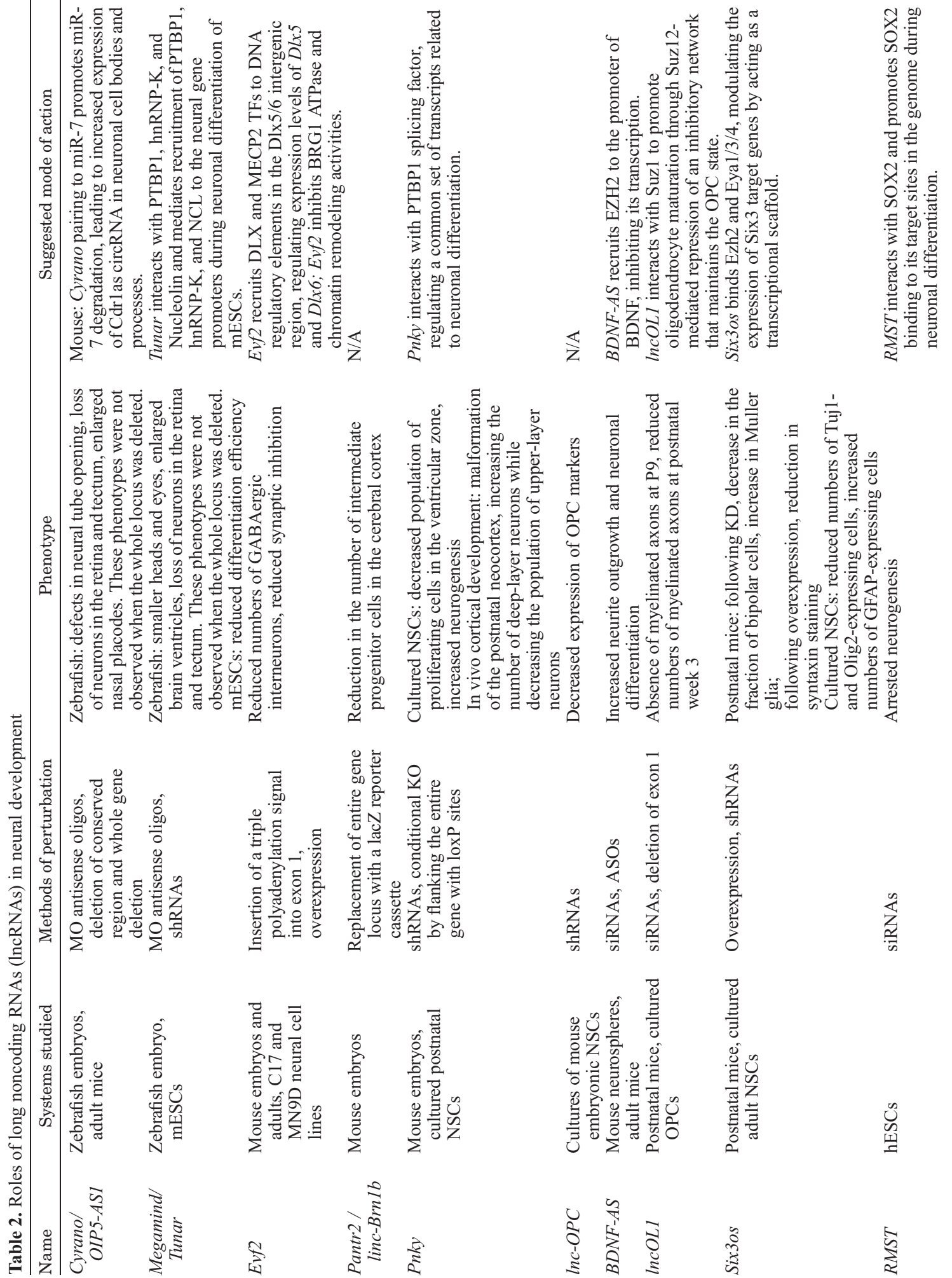

离离

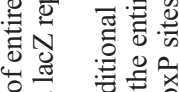

를

ठำ की

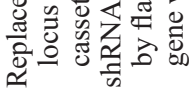
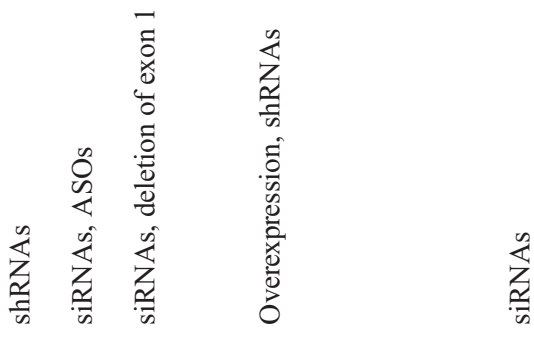

$\frac{n}{\mathrm{Z}}$
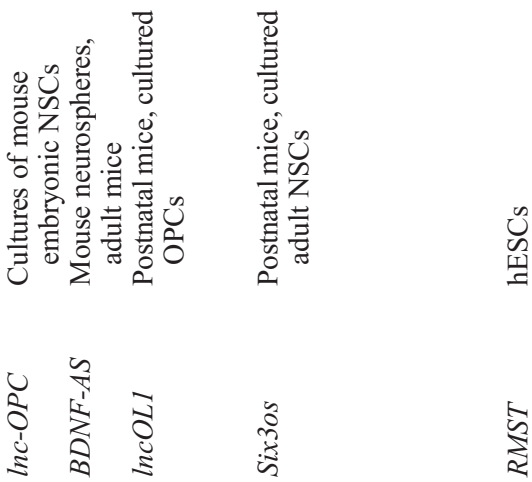


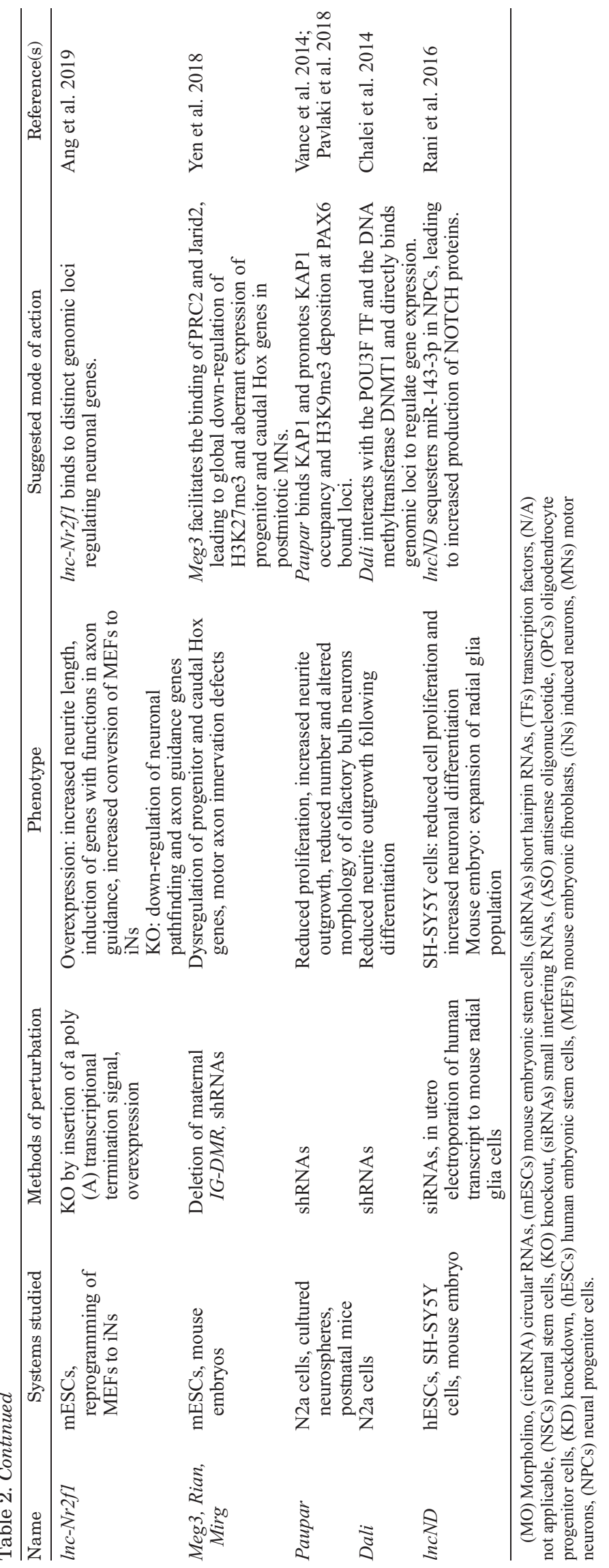


transcription factor (TF) and distally bind active promoters and regulate the expression of genes related to neuronal differentiation through physical association with the POU3F3 protein (Chalei et al. 2014).

The combination of different in vitro and in vivo systems can be used to efficiently characterize the functions of lncRNAs in neuronal differentiation. For example, $\ln c N D$, a primate-specific lncRNA, was found to regulate Notch signaling during neuronal differentiation by sequestering miR-143-3p (Rani et al. 2016). hESCs were used to characterize the expression dynamics of $\operatorname{lncND}$ during neuronal differentiation, siRNA transfection in SH-SY5Y cells was then used to study the functions of $\ln c N D$ during proliferation and differentiation, and, finally, injection of the human $\operatorname{lncND}$ transcript to the developing mouse cortex, which resulted in expansion of a radial glia population, supported the hypothesis that lncND contributed to the expansion of radial glia in higher primates (Rani et al. 2016).

\section{THE ROLE OF IncRNAS IN NEUROREGENERATION}

Neurons within the peripheral nervous system (PNS) can undergo axon outgrowth, which may lead to substantial functional recovery, while this process is limited within the CNS. Following axotomy, PNS neurons activate a unique regenerative transcriptional program and up-regulate numerous regeneration-associated genes (RAGs) (Curcio and Bradke 2018). The differences in the ability of CNS neurons to activate RAG expression, along with extracellular environmental factors, can explain why CNS neurons do not regenerate successfully (Ma and Willis 2015). Modulating critical hubs of RAG transcription can therefore have important therapeutic implications (Gao et al. 2016).

The next section describes the role of lncRNAs in nerve regeneration following different types of injuries, as demonstrated by in vitro and in vivo methods (Fig. 2 and Table 3).

\section{IncRNAs IN PERIPHERAL NERVE INJURY (PNI)}

Glial cells and molecules in the extracellular matrix (ECM) orchestrate axonal regeneration upon injury. Successful PNS axon regeneration is largely attributed to Schwann cell response via proliferation, migration, and remyelination (Toy and Namgung 2013). In parallel, in PNS neurons, multiple signaling pathways monitoring gene expression in the soma, together with pathways in the growth cone, control the balance of microtubule assembly, dynamics, and stabilization to achieve optimal axon growth (Glenn and Talbot 2013; Saijilafu et al. $2013 a, b)$. IncRNAs have been suggested to play important roles in these well-coordinated and complicated processes, in particular in stress responses, plasticity, and axonal outgrowth (Yu et al. 2013; Yao and Yu 2019). A common model to study mammalian axon regeneration in PNS neurons is sciatic nerve injury (SNI). The sensory neurons extending into the sciatic nerve are located in the L4-L6 dorsal root ganglia (DRGs) (Angius et al. 2012). The transcriptome of DRG neurons was studied using microarrays (Yu et al. 2013) and RNA-seq (Perry et al. 2018), and hundreds of genes were differentially expressed following SNI. In vitro, silencing of BC089918 and uc.217 using siRNAs in rat cultured neurons increased neurite outgrowth through an unknown mechanism (Yu et al. 2013; Yao et al. 2015), and uc.217 repression led to increased levels of Gal and Vip RAGs (Yao et al. 2015). We found that siRNA-mediated KD of Silc1 and Norris1 lncRNAs led to a reduction in total axonal outgrowth without any apparent effect on cell viability. Silc1 is transcribed from an intergenic region $200 \mathrm{~kb}$ upstream of the Sox $11 \mathrm{TF}$, a known master regulator of neurogenesis that has been shown to be required for both embryonic and adult neurogenesis in mice (Jankowski et al. 2006, 2009, 2018). To study Silc1 function in vivo, we generated Silc1 KO mice by deletion of Silc1 promoter and exon 1 using CRISPRCas9. Silc1 KO mice have reduced levels of Sox11 in neuronal cells and exhibit delayed regeneration following
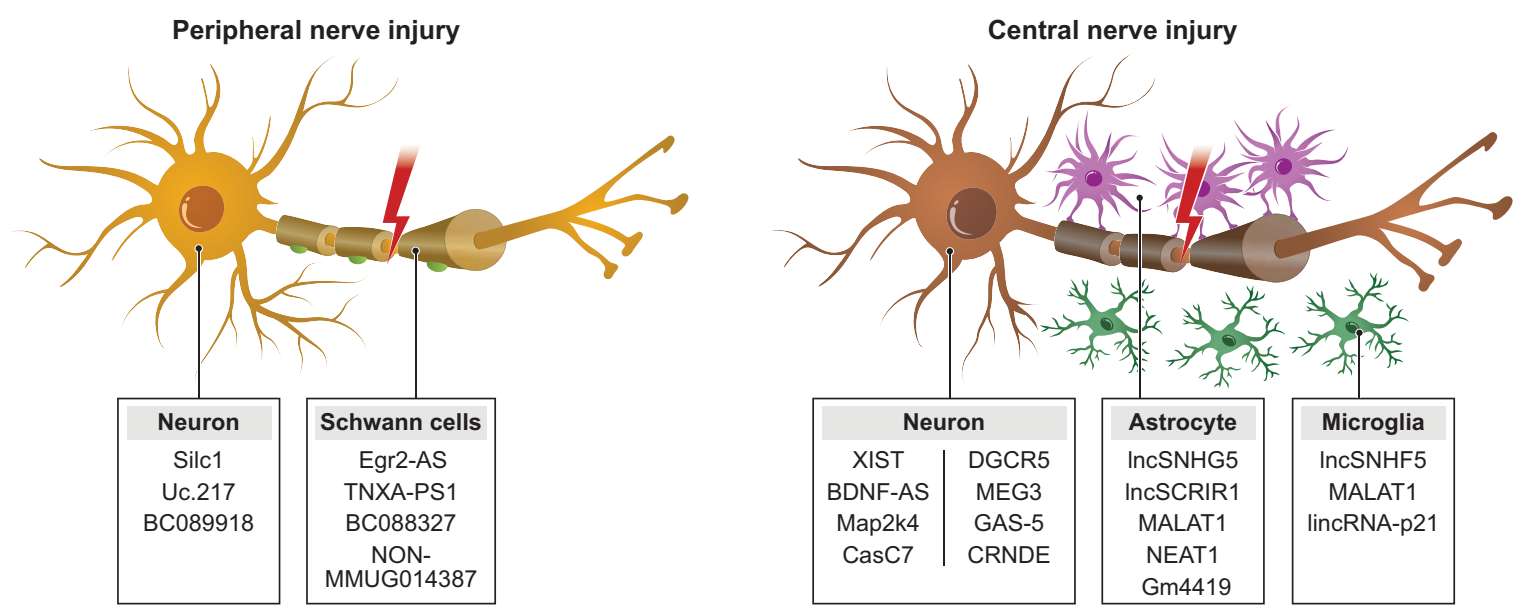

Figure 2. Long noncoding RNAs (lncRNAs) implicated in response to neuronal injury. Names of lncRNAs are indicated next to the cell types and injury types in which they have been studied. 
Table 3. Roles of long noncoding RNAs (lncRNAs) in neuroregeneration

\begin{tabular}{|c|c|c|c|c|c|}
\hline Name & Systems studied & $\begin{array}{l}\text { Methods of } \\
\text { perturbation }\end{array}$ & Phenotype & $\begin{array}{l}\text { Suggested mode of } \\
\text { action }\end{array}$ & Reference(s) \\
\hline ВC089918 & $\begin{array}{l}\text { SNI in rat model } \\
\text { and DRG culture } \\
\text { cells }\end{array}$ & siRNAs & $\begin{array}{l}\text { Negative effect on neurite } \\
\text { outgrowth of DRG } \\
\text { culture cells }\end{array}$ & N/A & Yu et al. 2013 \\
\hline Uc. 217 & $\begin{array}{l}\text { SNI in rat model } \\
\text { and DRG culture } \\
\text { cells }\end{array}$ & siRNAs & $\begin{array}{l}\text { Negative effect on neurite } \\
\text { outgrowth of DRG } \\
\text { culture cells }\end{array}$ & N/A & Yao et al. 2015 \\
\hline Silc1 & $\begin{array}{l}\text { SNI in mouse and } \\
\text { DRG culture cells }\end{array}$ & $\begin{array}{l}\text { siRNAs, KO by } \\
\text { deletion of promoter } \\
\text { and first exon }\end{array}$ & $\begin{array}{l}\text { Reduction in total axonal } \\
\text { outgrowth; delayed } \\
\text { regeneration following } \\
\text { sciatic injury }\end{array}$ & $\begin{array}{l}\text { cis-acting activation } \\
\text { of Sox11 }\end{array}$ & $\begin{array}{l}\text { Perry et al. } \\
2018\end{array}$ \\
\hline NONMMUG014387 & $\begin{array}{l}\text { SNI in mouse and } \\
\text { Schwann cells }\end{array}$ & Overexpression & $\begin{array}{l}\text { Increased proliferation of } \\
\text { Schwann cells }\end{array}$ & $\begin{array}{l}\text { Activation of Wnt/ } \\
\text { PCP pathway }\end{array}$ & $\begin{array}{l}\text { Pan et al. } \\
\text { 2017a }\end{array}$ \\
\hline ВC088327 & $\begin{array}{l}\text { Rat SNI and mouse } \\
\text { Schwann cells }\end{array}$ & siRNAs & $\begin{array}{l}\text { Increased Schwann cells } \\
\text { proliferation }\end{array}$ & $\mathrm{N} / \mathrm{A}$ & $\begin{array}{l}\text { Wang et al. } \\
2018\end{array}$ \\
\hline Egr2-AS & $\begin{array}{l}\text { Mouse SNI and } \\
\text { DRG explant } \\
\text { culture }\end{array}$ & $\begin{array}{l}\text { Overexpression, } \\
\text { GapmeRs }\end{array}$ & Increased demyelination & $\begin{array}{l}\text { Inhibition of Egr2 } \\
\text { expression }\end{array}$ & $\begin{array}{l}\text { Martinez- } \\
\text { Moreno } \\
\text { et al. } 2017\end{array}$ \\
\hline TNXA-PS1 & $\begin{array}{l}\text { Rat SNI and } \\
\text { Schwann cells } \\
\text { culture }\end{array}$ & siRNAs & $\begin{array}{l}\text { Reduced Schwann cell } \\
\text { migration }\end{array}$ & $\begin{array}{l}\text { Sponging miR-24- } \\
3 \mathrm{p} / \mathrm{miR}-152-3 \mathrm{p} \\
\text { and regulation of } \\
\text { Dusp1 }\end{array}$ & Yao et al. 2018 \\
\hline$B D N F-A S$ & $\begin{array}{l}\text { Rat acute SCI and } \\
\text { hypoxia cellular } \\
\text { model, neuronal } \\
\text { cell lines }\end{array}$ & siRNAs & $\begin{array}{l}\text { Increased neuronal cell } \\
\text { apoptosis }\end{array}$ & $\begin{array}{l}\text { Sponging miR- } \\
130 \mathrm{~b}-5 \mathrm{p} \text { to } \\
\text { regulate PRDM5 }\end{array}$ & $\begin{array}{l}\text { Zhang et al. } \\
2018 \mathrm{a}\end{array}$ \\
\hline$D G C R 5$ & $\begin{array}{l}\text { Rat acute SCI and } \\
\text { hypoxia cellular } \\
\text { model, neuronal } \\
\text { cell lines }\end{array}$ & siRNAs & $\begin{array}{l}\text { Reduced neuronal } \\
\text { apoptosis }\end{array}$ & $\begin{array}{l}\text { Binding and } \\
\text { negative } \\
\text { regulation of } \\
\text { PRDM5 }\end{array}$ & $\begin{array}{l}\text { Zhang et al. } \\
2018 b\end{array}$ \\
\hline SNHG5 & $\begin{array}{l}\text { Rat SCI and } \\
\text { primary cultured } \\
\text { astrocytes }\end{array}$ & $\begin{array}{l}\text { siRNAs, } \\
\text { overexpression }\end{array}$ & $\begin{array}{l}\text { Enhanced viability of } \\
\text { astrocytes and microglia }\end{array}$ & N/A & $\begin{array}{l}\text { Jiang and } \\
\text { Zhang } 2018\end{array}$ \\
\hline GAS5 & $\begin{array}{l}\text { Mouse TBI and } \\
\text { primary culture } \\
\text { neuronal cells }\end{array}$ & siRNAs & $\begin{array}{l}\text { Increased neuronal } \\
\text { apoptosis }\end{array}$ & $\begin{array}{l}\text { Sponging miR-335 } \\
\text { to activate Rasal }\end{array}$ & $\begin{array}{l}\text { Wang et al. } \\
\text { 2017; Dai } \\
\text { et al. } 2019\end{array}$ \\
\hline$C R N D E$ & Rat TBI & siRNAs & Increased nerve repair & $\mathrm{N} / \mathrm{A}$ & Yi et al. 2019 \\
\hline
\end{tabular}

(SNI) Spinal nerve injury, (DRG) dorsal root ganglion, (siRNAs) small interfering RNAs, (N/A) not applicable, (KO) knockout, (SCI) spinal cord injury, (TBI) traumatic brain injury.

SNI. Therefore, Silc1 regulates neuroregeneration in cultured cells and in vivo, through cis-acting activation of the Sox $11 \mathrm{TF}$, through a currently unknown mechanism (Perry et al. 2018).

IncRNAs are also important for Schwann cells regulation after PNI. IncRNAs in Schwann cells were profiled using microarrays with RNA from the distal segment of the mouse sciatic nerve, where the Wallerian degeneration process occurs (Pan et al. 2017b). One of these, NONMMUG014387, promoted mouse Schwann cell proliferation by increasing Cthrcl expression and activating the Wnt/PCP pathway (Pan et al. 2017a). IncRNA BC088327 was implicated in Schwann cell proliferation in a rat model with SNI after treatment with Heregulin-1 $\beta$. $B C 088327$ may play a synergistic role with heregulin- $1 \beta$ in repairing PNI (Wang et al. 2018).

The myelination process is also crucial for PNS nerve regeneration. Recently it was found that the EGR2 TF is an important modulator in this process in mice. Egr2 is down-regulated during SNI, whereas Egr2-AS lncRNA, transcribed antisense to the proximal promoter of $E g r 2$, is up-regulated. Overexpressing $E g r 2-A S$ in mouse DRG explant cultures results in inhibition of Egr2 mRNA ex- pression and induces demyelination, suggesting that this IncRNA acts in trans. Inhibition of Egr2-AS in vivo using GapmeRs at the time of SNI, rescues the inhibition of Egr2 transcript expression and affects EGR2-regulated genes to delay demyelination. Mechanistically, it was proposed that $E g r 2-A S$ recruits $\mathrm{H} 3 \mathrm{~K} 27 \mathrm{me} 3, \mathrm{AGO} 1, \mathrm{AGO}$, and EZH2 to the $E g r 2$ promoter following SNI. Furthermore, expression of Egr2-AS is regulated through ERK1/2 signaling to YY1 (Martinez-Moreno et al. 2017).

An additional important process in PNS regeneration is Schwann cell migration, which can precede and enhance axonal repair by guiding axon reinnervation and controlling synaptic formation. Silencing of the TNAX-PS1 lncRNA in vitro and in vivo by siRNAs promoted Schwann cell migration. Additional experiments showed that TNXA-PSI might exert its regulatory role by sponging miR-24-3p/miR-152-3p and affecting Dusp1 expression (Yao et al. 2018).

\section{IncRNAs IN SPINAL CORD INJURY}

Primary spinal cord injury (SCI) is commonly caused by direct trauma or pathological alterations; it is much 
more complicated than PNI because of extensive cell loss, axonal disruption, glial scar, and shortage of growthpermissive factors (Estrada and Müller 2014). This is followed by secondary injury mechanisms, including glutaminergic excitotoxicity, oxidative stress, increased adaptive immune responses, Wallerian degeneration, and scar tissue formation, leading to further structural and functional disturbances (Ahuja et al. 2017). Various types of ncRNAs were implicated in these processes (Ning et al. 2014; Qin et al. 2018; Li et al. 2019b; Pinchi et al. 2019; Yao and Yu 2019; Zhou et al. 2019). The roles of lncRNAs after SCI have been recently thoroughly reviewed (Li et al. $2019 b$ ), and so we will present only a few examples here. $B D N F-A S$ lncRNA is up-regulated in a rat acute SCI model. $B D N F-A S$ KD by siRNAs in neuronal cell lines reduced neuronal cell apoptosis in hypoxic conditions. It was suggested that $B D N F-A S$ associates with miR-130b$5 \mathrm{p}$, which is repressed during SNI. In vivo, $B D N F-A S \mathrm{KD}$ with siRNAs inhibited the expression of PRDM5, supposedly through competitive binding with miR-130b-5p, resulting in decreased apoptosis (Zhang et al. 2018a). In contrast, DGCR5 lncRNA was down-regulated in this model and in neurons treated with hypoxia (Zhang et al. 2018 b). Using in vitro and in vivo methods it was shown that DGCR5 suppresses neuronal apoptosis through directly binding and negatively regulating PRDM5, thereby ameliorating SCI (Zhang et al. 2018b).

lncRNA SNHG5 is an example of a lncRNA that is induced following SCI and enhances the viability of astrocytes and microglia. SNHG5 overexpression promoted cell viability of both astrocytes or microglia, while its down-regulation by siRNAs led to cell death (Jiang and Zhang 2018). SNHG5 overexpression in vivo results in reduced motor recovery post-SCI in rats. Additional experiments demonstrated that SNHG5 enhances the expression of both KLF4 and eNOS (Jiang and Zhang 2018). Additional lncRNAs that have a proposed role in SCI are IncSCRIR1, Casc7, MALAT1, XIST, and Map2K4 (Li et al. 2019b).

\section{IncRNAs IN TRAUMATIC BRAIN INJURY}

Traumatic brain injury (TBI) is a significant source of morbidity and mortality in the adult population. TBI causes secondary biochemical changes that contribute to neurological dysfunction, delayed neuroinflammation, and nerve cell death (Kabadi and Faden 2014). IncRNA dysregulation after TBI was observed in the cerebral cortex and hippocampus (Zhong et al. 2016; Wang et al. 2017). The current progress of studies on lncRNAs in TBI was recently reviewed (Zhang and Wang 2019; Li et al. 2019a), so we will mention only few examples that were recently published. Gas 5 was found using microarrays to be induced in the rat hippocampus after TBI (Wang et al. 2017). In mouse neuronal cells GAS5 could up-regulate Rasal expression and promote neuronal apoptosis following TBI. In vivo experiments indicated that Changqin NO. 1, a traditional Chinese medicine, had neuroprotective effects by inhibiting neuronal apoptosis via the GAS5/
miR-335/Rasa1 axis (Dai et al. 2019). Furthermore, GAS5 silencing protected against hypoxic/ischemic-induced brain injury in vivo and primary hippocampal neuron injury in vitro, suggesting a potential therapeutic approach of GAS5 inhibition in the treatment of neonatal brain damage (Wang et al. 2017; Zhao et al. 2018).

$C R N D E$ was up-regulated in serum of TBI patients compared to healthy controls. In vivo studies using TBI rat model showed that silencing of CRNDE improves neurobehavioral function, inhibits the expression of neuroinflammatory factors, and inhibits neuronal apoptosis and autophagy in TBI rats. Repression of CRNDE also promoted the expression of differentiation markers in neurons and the directional growth and regeneration of nerve fibers (Yi et al. 2019). Other lncRNAs that have a reported function in TBI are NEAT1, MEG3, MALAT1, Gm4419, and lincRNA-p21 (Li et al. 2019a; Zhang and Wang 2019).

\section{IncRNAs IN NEUROLOGICAL DISEASES}

Supporting the importance of lncRNAs in the development and functions of the CNS, dysregulation of lncRNAs in the nervous system has been linked with changes occurring in human neurological diseases, including neurodegenerative diseases and psychiatric disorders.

Miat (also known as Gomafu) is a lncRNA that is localized to a subnuclear domain in a distinct subset of differentiating neurons in the mouse nervous system (Sone et al. 2007; Mercer et al. 2010), and its expression is regulated by neuronal activity (Barry et al. 2014). Miat is down-regulated in postmortem cortex of subjects with and its $\mathrm{KD}$ in neuronal cultures led to changes in alternative splicing that resembled those observed in schizophrenia patients (Barry et al. 2014). Another study identified 125 lncRNAs with aberrant expression in schizophrenia patients (Chen et al. 2016), and a co-expression network analysis suggested that specific lncRNAs are associated with early-onset schizophrenia (Ren et al. 2015).

$B A C E 1-A S$ was shown to regulate the expression level of $B A C E 1$, a crucial enzyme in Alzheimer's disease (AD) pathophysiology. $B A C E 1-A S$ levels were elevated in subjects with $\mathrm{AD}$ and in amyloid precursor protein transgenic mice (Faghihi et al. 2008). Several other lncRNAs have been suggested to have roles in AD (Luo and Chen 2016), and microarray analysis of postmortem AD tissues (Zhou and $\mathrm{Xu}$ 2015) and a rat model of AD (Zhou and Xu 2015; Yang et al. 2017) identified hundreds of dysregulated lncRNAs.

The expression level of Megamind/TUNA lncRNA, discussed above, was shown to be associated with Huntington's disease (HD) neuropathological grade in patients' brains (Lin et al. 2014), and a microarray-based study found that several lncRNAs, including TUG1, NEAT1, $M E G 3$, and DGCR5, are dysregulated in the brains of HD patients (Johnson 2012).

Different lncRNAs, such as naPINK1, NEAT1 PINK1$A S, B C 200$, and Sox2OT, were found to be dysregulated in Parkinson's disease (PD) patients' brains (Wan et al. 2017). Recently it was found that IncRNA Neatl is 
significantly up-regulated in the midbrain of PD mice, and it was suggested that Neat1 promotes MPTP-induced autophagy in PD by stabilizing PINK1 protein (Yan et al. 2018).

An increasing number of studies report on lncRNAs as being implicated in additional neurodegenerative diseases including amyotrophic lateral sclerosis (ALS), multiple system atrophy (MSA), frontotemporal lobar degeneration (FTLD), and glaucoma (Riva et al. 2016; Quan et al. 2017; Wan et al. 2017; Wang et al. 2017).

\section{CONCEPTUAL ROLES OF IncRNAS IN THE NERVOUS SYSTEM}

We summarized here a large number of recent reports on various functional outcomes of lncRNA perturbations in the nervous system. What ties together these observations? One trend is that a large number of the observed phenotypes were related to changes in proliferation of progenitors or their ability to give rise to particular populations. Importantly, these are also likely the easiest phenotypes to score in the nervous system, which provides a possible explanation for their prevalence in the literature.

Beyond the need to regulate the balance between proliferation and differentiation and to specify and then "lock" different fates, cells in the nervous system have several features that may be particularly prone to lncRNA regulation. First, the vast majority of the cells in the adult nervous system are postmitotic and so cannot rely on replication-dependent histone exchange for chromatin regulation. Transcription- or lncRNA-mediated effects thus may replace some of the regulatory processes that rely more heavily on replication-associated mechanisms in more proliferative cells (e.g., in colon or blood). Such mechanisms likely play an outsized role in the ability of neurons to regenerate in the absence of cell proliferation. Another prominent feature of the nervous system is the requirement for rapid changes in gene expression upon specific cues, such as neuronal activity, which requires maintenance of chromatin in a particularly poised state, as well as extensive post-transcriptional regulation, that acts to limit the expression window of genes induced in the early stages of the response or allows fast maturation and export of particularly long genes (Mauger et al. 2016). Last, the size and complex morphology of neural cells dictate the need for complex post-transcriptional regulation, which may benefit from RNA-based control. Future studies will elucidate which of these or other features of the neural environment preferentially rely on lncRNA function and may explain why neural cells express a particularly vibrant complement of lncRNA genes.

\section{ACKNOWLEDGMENTS}

Research in the Ulitsky laboratory is supported by the Israel Science Foundation (2406/18 and 852/19); European Research Council project lincSAFARI; MOST-PRC program; German-Israel foundation for Scientific Research and Development (GIF, I-1455-417.13/2018);
The EU Joint Programme-Neurodegenerative Disease Research (JPND ERA-Net localMND); BIRAX — Britain Israel Research and Academic Exchange Partnership; United States-Israel Binational Science Foundation; Lapon Raymond; and the Abramson Family Center for Young Scientists. I.U. is incumbent of the Sygnet Career Development Chair for Bioinformatics.

\section{REFERENCES}

Ahuja CS, Wilson JR, Nori S, Kotter MRN, Druschel C, Curt A, Fehlings MG. 2017. Traumatic spinal cord injury. Nat Rev Dis Primers 3: 17018. doi:10.1038/nrdp.2017.18

Andersen RE, Hong SJ, Lim JJ, Cui M, Harpur BA, Hwang E, Delgado RN, Ramos AD, Liu SJ, Blencowe BJ, et al. 2019. The long noncoding RNA Pnky is a trans-acting regulator of cortical development in vivo. Dev Cell 49: 632-642.e7. doi:10 $.1016 /$ j.devcel.2019.04.032

Anderson KM, Anderson DM, McAnally JR, Shelton JM, Bassel-Duby R, Olson EN. 2016. Transcription of the non-coding RNA upperhand controls Hand2 expression and heart development. Nature 539: 433-436. doi:10.1038/nature20128

Ang CE, Ma Q, Wapinski OL, Fan S, Flynn RA, Lee QY, Coe B, Onoguchi M, Olmos VH, Do BT, et al. 2019. The novel IncRNA is pro-neurogenic and mutated in human neurodevelopmental disorders. Elife 8: e41770. doi:10.7554/eLife .41770

Angius D, Wang H, Spinner RJ, Gutierrez-Cotto Y, Yaszemski MJ, Windebank AJ. 2012. A systematic review of animal models used to study nerve regeneration in tissue-engineered scaffolds. Biomaterials 33: 8034-8039.

Barry G, Briggs JA, Vanichkina DP, Poth EM, Beveridge NJ, Ratnu VS, Nayler SP, Nones K, Hu J, Bredy TW, et al. 2014. The long non-coding RNA Gomafu is acutely regulated in response to neuronal activation and involved in schizophrenia-associated alternative splicing. Mol Psychiatry 19: 486494. doi: $10.1038 / \mathrm{mp} .2013 .45$

Bassett AR, Akhtar A, Barlow DP, Bird AP, Brockdorff N, Duboule D, Ephrussi A, Ferguson-Smith AC, Gingeras TR, Haerty W, et al. 2014. Considerations when investigating IncRNA function in vivo. Elife 3: e03058. doi:10.7554/eLife .03058

Bond AM, Vangompel MJW, Sametsky EA, Clark MF, Savage JC, Disterhoft JF, Kohtz JD. 2009. Balanced gene regulation by an embryonic brain ncRNA is critical for adult hippocampal GABA circuitry. Nat Neurosci 12: 1020-1027. doi:10.1038/ nn.2371

Briese M, Saal L, Appenzeller S, Moradi M, Baluapuri A, Sendtner M. 2016. Whole transcriptome profiling reveals the RNA content of motor axons. Nucleic Acids Res 44: e33. doi:10 $.1093 /$ nar/gkv1027

Cabili MN, Trapnell C, Goff L, Koziol M, Tazon-Vega B, Regev A, Rinn JL. 2011. Integrative annotation of human large intergenic noncoding RNAs reveals global properties and specific subclasses. Genes Dev 25: 1915-1927. doi:10.1101/gad .17446611

Cabili MN, Dunagin MC, McClanahan PD, Biaesch A, PadovanMerhar O, Regev A, Rinn JL, Raj A. 2015. Localization and abundance analysis of human lncRNAs at single-cell and single-molecule resolution. Genome Biol 16: 20. doi:10.1186/ s13059-015-0586-4

Cajigas I, Leib DE, Cochrane J, Luo H, Swyter KR, Chen S, Clark BS, Thompson J, Yates JR, Kingston RE, et al. 2015. Evf2 lncRNA/BRG1/DLX1 interactions reveal RNA-dependent inhibition of chromatin remodeling. Development 142: 2641-2652. doi:10.1242/dev.126318

Cajigas I, Chakraborty A, Swyter KR, Luo H, Bastidas M, Nigro M, Morris ER, Chen S, VanGompel MJW, Leib D, et al. 2018. The Evf2 ultraconserved enhancer lncRNA functionally and spatially organizes megabase distant genes in the developing 
forebrain. Mol Cell 71: 956-972.e9. doi:10.1016/j.molcel .2018 .07 .024

Chalei V, Sansom SN, Kong L, Lee S, Montiel JF, Vance KW, Ponting CP. 2014. The long non-coding RNA Dali is an epigenetic regulator of neural differentiation. Elife 3: e04530. doi:10.7554/eLife.04530

Chen S, Sun X, Niu W, Kong L, He M, Li W, Zhong A, Lu J, Zhang L. 2016. Aberrant expression of long non-coding RNAs in schizophrenia patients. Med Sci Monit 22: 3340-3351. doi:10.12659/MSM.896927

Curcio M, Bradke F. 2018. Axon regeneration in the central nervous system: facing the challenges from the inside. Annu Rev Cell Dev Biol 34: 495-521. doi:10.1146/annurev-cellbio100617-062508

Dai X, Yi M, Wang D, Chen Y, Xu X. 2019. Changqin NO. 1 inhibits neuronal apoptosis via suppressing GAS5 expression in a traumatic brain injury mice model. Biol Chem 400: 753763. doi:10.1515/hsz-2018-0340

Derrien T, Johnson R, Bussotti G, Tanzer A, Djebali S, Tilgner H, Guernec G, Martin D, Merkel A, Knowles DG, et al. 2012. The GENCODE v7 catalog of human long noncoding RNAs: analysis of their gene structure, evolution, and expression. Genome Res 22: 1775-1789. doi:10.1101/gr.132159.111

Dong X, Chen K, Cuevas-Diaz Duran R, You Y, Sloan SA, Zhang Y, Zong S, Cao Q, Barres BA, Wu JQ. 2015. Comprehensive identification of long non-coding RNAs in purified cell types from the brain reveals functional lncRNA in OPC fate determination. PLoS Genet 11: e1005669. doi:10.1371/ journal.pgen.1005669

Ebbesen KK, Kjems J, Hansen TB. 2016. Circular RNAs: identification, biogenesis and function. Biochim Biophys Acta 1859: 163-168. doi:10.1016/j.bbagrm.2015.07.007

Estrada V, Müller HW. 2014. Spinal cord injury - there is not just one way of treating it. F1000Prime Rep 6: 84. doi:10.12703/ P6-84

Faghihi MA, Modarresi F, Khalil AM, Wood DE, Sahagan BG, Morgan TE, Finch CE, St Laurent G III, Kenny PJ, Wahlestedt C. 2008. Expression of a noncoding RNA is elevated in Alzheimer's disease and drives rapid feed-forward regulation of $\beta$-secretase. Nat Med 14: 723-730. doi:10.1038/ nm1784

Farris S, Ward JM, Carstens KE, Samadi M, Wang Y, Dudek SM. 2019. Hippocampal subregions express distinct dendritic transcriptomes that reveal differences in mitochondrial function in CA2. Cell Rep 29: 522-539.e6. doi:10.1016/j.celrep .2019 .08 .093

Feng J, Bi C, Clark BS, Mady R, Shah P, Kohtz JD. 2006. The Evf-2 noncoding RNA is transcribed from the Dlx-5/6 ultraconserved region and functions as a Dlx-2 transcriptional coactivator. Genes Dev 20: 1470-1484. doi:10.1101/gad .1416106

Gao Y, Yang Z, Li X. 2016. Regeneration strategies after the adult mammalian central nervous system injury-biomaterials. Regen Biomater 3: 115-122. doi:10.1093/rb/rbw004

Glenn TD, Talbot WS. 2013. Signals regulating myelination in peripheral nerves and the Schwann cell response to injury. Curr Opin Neurobiol 23: 1041-1048. doi:10.1016/j.conb .2013 .06 .010

Goff LA, Groff AF, Sauvageau M, Trayes-Gibson Z, SanchezGomez DB, Morse M, Martin RD, Elcavage LE, Liapis SC, Gonzalez-Celeiro M, et al. 2015. Spatiotemporal expression and transcriptional perturbations by long noncoding RNAs in the mouse brain. Proc Natl Acad Sci 112: 6855-6862. doi:10 $.1073 /$ pnas. 1411263112

Goudarzi M, Berg K, Pieper LM, Schier AF. 2019. Individual long non-coding RNAs have no overt functions in zebrafish embryogenesis, viability and fertility. Elife 8: e40815. doi:10 $.7554 /$ eLife. 40815

Han X, Zhang J, Liu Y, Fan X, Ai S, Luo Y, Li X, Jin H, Luo S, Zheng H, et al. 2019. The lnc RNA Hand2os1/Uph orchestrates heart development through regulation of precise expression of Hand2. Development 146: dev176198. doi:10.1242/ dev. 176198
He D, Wang J, Lu Y, Deng Y, Zhao C, Xu L, Chen Y, Hu Y-C, Zhou W, Lu QR. 2017. IncRNA functional networks in oligodendrocytes reveal stage-specific myelination control by an IncOL1/Suz12 complex in the CNS. Neuron 93: 362-378. doi:10.1016/j.neuron.2016.11.044

Jankowski MP, Cornuet PK, McIlwrath S, Koerber HR, Albers KM. 2006. SRY-box containing gene 11 (Sox11) transcription factor is required for neuron survival and neurite growth. $\mathrm{Neu}$ roscience 143: 501-514. doi:10.1016/j.neuroscience.2006.09 .010

Jankowski MP, McIlwrath SL, Jing X, Cornuet PK, Salerno KM, Koerber HR, Albers KM. 2009. Sox11 transcription factor modulates peripheral nerve regeneration in adult mice. Brain Res 1256: 43-54. doi:10.1016/j.brainres.2008.12.032

Jankowski MP, Miller L, Richard Koerber H. 2018. Increased expression of transcription factor SRY-box-containing gene 11 (Sox11) enhances neurite growth by regulating neurotrophic factor responsiveness. Neuroscience 382: 93-104. doi:10 .1016/j.neuroscience.2018.04.037.

Jiang Z-S, Zhang J-R. 2018. lncRNA SNHG5 enhances astrocytes and microglia viability via upregulating KLF4 in spinal cord injury. Int J Biol Macromol 120: 66-72. doi:10.1016/j .ijbiomac.2018.08.002.

Johnson R. 2012. Long non-coding RNAs in Huntington's disease neurodegeneration. Neurobiol Dis 46: 245-254. doi:10 $.1016 /$ j.nbd.2011.12.006.

Kabadi SV, Faden AI. 2014. Neuroprotective strategies for traumatic brain injury: improving clinical translation. Int $\mathrm{J} \mathrm{Mol} \mathrm{Sci}$ 15: 1216-1236.

Kleaveland B, Shi CY, Stefano J, Bartel DP. 2018. A network of noncoding regulatory RNAs acts in the mammalian brain. Cell 174: 350-362.e17. doi:10.1016/j.cell.2018.05.022

Kok FO, Shin M, Ni C-W, Gupta A, Grosse AS, van Impel A, Kirchmaier BC, Peterson-Maduro J, Kourkoulis G, Male I, et al. 2015. Reverse genetic screening reveals poor correlation between morpholino-induced and mutant phenotypes in zebrafish. Dev Cell 32: 97-108. doi:10.1016/j.devcel.2014.11.018

Kopp F, Mendell JT. 2018. Functional classification and experimental dissection of long noncoding RNAs. Cell 172: $393-$ 407. doi:10.1016/j.cell.2018.01.011

Lavalou P, Eckert H, Damy L, Constanty F, Majello S, Bitetti A, Graindorge A, Shkumatava A. 2019. Strategies for genetic inactivation of long noncoding RNAs in zebrafish. RNA 25: 897-904. doi:10.1261/rna.069484.118

Li Z, Han K, Zhang D, Chen J, Xu Z, Hou L. 2019a. The role of long noncoding RNA in traumatic brain injury. Neuropsychiatr Dis Treat 15: 1671-1677. doi:10.2147/NDT.S206624

Li Z, Ho IHT, Li X, Xu D, Wu WKK, Chan MTV, Li S, Liu X. 2019b. Long non-coding RNAs in the spinal cord injury: novel spotlight. J Cell Mol Med 23: 4883-4890. doi:10.1111/jcmm .14422

Lin N, Chang K-Y, Li Z, Gates K, Rana ZA, Dang J, Zhang D, Han T, Yang C-S, Cunningham TJ, et al. 2014. An evolutionarily conserved long noncoding RNA TUNA controls pluripotency and neural lineage commitment. Mol Cell 53: 1005-1019. doi:10.1016/j.molcel.2014.01.021

Luo Q, Chen Y. 2016. Long noncoding RNAs and Alzheimer's disease. Clin Interv Aging 11: 867-872. doi:10.2147/cia .s107037

Ma TC, Willis DE. 2015. What makes a RAG regeneration associated? Front Mol Neurosci 8: 43. doi:10.3389/fnmol.2015 .00043

Martinez-Moreno M, O’Shea TM, Zepecki JP, Olaru A, Ness JK, Langer R, Tapinos N. 2017. Regulation of peripheral myelination through transcriptional buffering of Egr2 by an antisense long non-coding RNA. Cell Rep 20: 1950-1963. doi:10.1016/j.celrep.2017.07.068

Mauger O, Lemoine F, Scheiffele P. 2016. Targeted intron retention and excision for rapid gene regulation in response to neuronal activity. Neuron 92: 1266-1278. doi:10.1016/j.neuron .2016.11.032

Mercer TR, Dinger ME, Sunkin SM, Mehler MF, Mattick JS. 2008. Specific expression of long noncoding RNAs in the 
mouse brain. Proc Natl Acad Sci 105: 716-721. doi:10.1073/ pnas.0706729105

Mercer TR, Qureshi IA, Gokhan S, Dinger ME, Li G, Mattick JS, Mehler MF. 2010. Long noncoding RNAs in neuronal-glial fate specification and oligodendrocyte lineage maturation. BMC Neurosci 11: 14. doi:10.1186/1471-2202-11-14

Minis A, Dahary D, Manor O, Leshkowitz D, Pilpel Y, Yaron A. 2014. Subcellular transcriptomics - dissection of the mRNA composition in the axonal compartment of sensory neurons. Dev Neurobiol 74: 365-381. doi:10.1002/dneu.22140.

Modarresi F, Faghihi MA, Lopez-Toledano MA, Fatemi RP, Magistri M, Brothers SP, van der Brug MP, Wahlestedt C. 2012. Inhibition of natural antisense transcripts in vivo results in gene-specific transcriptional upregulation. Nat Biotechnol 30: 453-459. doi:10.1038/nbt. 2158

Ng S-Y, Johnson R, Stanton LW. 2012. Human long non-coding RNAs promote pluripotency and neuronal differentiation by association with chromatin modifiers and transcription factors. EMBO J 31: 522-533. doi:10.1038/emboj.2011.459

Ng S-Y, Bogu GK, Soh BS, Stanton LW. 2013. The long noncoding RNA RMST interacts with SOX2 to regulate neurogenesis. Mol Cell 51: 349-359. doi:10.1016/j.molcel.2013 .07 .017

Nijssen J, Aguila J, Hoogstraaten R, Kee N, Hedlund E. 2018. Axon-seq decodes the motor axon transcriptome and its modulation in response to ALS. Stem Cell Rep 11: 1565-1578. doi:10.1016/j.stemcr.2018.11.005

Ning B, Gao L, Liu R-H, Liu Y, Zhang N-S, Chen Z-Y. 2014. microRNAs in spinal cord injury: potential roles and therapeutic implications. Int J Biol Sci 10: 997-1006. doi:10.7150/ijbs .9058

Pan B, Shi Z-J, Yan J-Y, Li J-H, Feng S-Q. 2017a. Long noncoding RNA NONMMUG014387 promotes Schwann cell proliferation after peripheral nerve injury. Neural Regen Res 12: 2084-2091. doi:10.4103/1673-5374.221168

Pan B, Zhou H-X, Liu Y, Yan J-Y, Wang Y, Yao X, Deng Y-Q, Chen S-Y, Lu L, Wei Z-J, et al. 2017b. Time-dependent differential expression of long non-coding RNAs following peripheral nerve injury. Int J Mol Med 39: 1381-1392. doi:10 $.3892 /$ ijmm.2017.2963

Pavlaki I, Alammari F, Sun B, Clark N, Sirey T, Lee S, Woodcock DJ, Ponting CP, Szele FG, Vance KW. 2018. The long noncoding RNA Paupar promotes KAP1-dependent chromatin changes and regulates olfactory bulb neurogenesis. EMBO J 37: e98219. doi:10.15252/embj.201798219.

Perry RB-T, Hezroni H, Goldrich MJ, Ulitsky I. 2018. Regulation of neuroregeneration by long noncoding RNAs. Mol Cell 72: 553-567.e5. doi:10.1016/j.molcel.2018.09.021

Pinchi E, Frati A, Cantatore S, D'Errico S, Russa RL, Maiese A, Palmieri M, Pesce A, Viola RV, Frati P, et al. 2019. Acute spinal cord injury: a systematic review investigating miRNA families involved. Int J Mol Sci 20: E1841. doi:10.3390/ ijms20081841.

Piwecka M, Glažar P, Hernandez-Miranda LR, Memczak S, Wolf SA, Rybak-Wolf A, Filipchyk A, Klironomos F, Cerda Jara CA, Fenske P, et al. 2017. Loss of a mammalian circular RNA locus causes miRNA deregulation and affects brain function. Science 357: eaam8526. doi:10.1126/science.aam8526.

Qin C, Liu C-B, Yang D-G, Gao F, Zhang X, Zhang C, Du L-J, Yang M-L, Li J-J. 2018. Circular RNA expression alteration and bioinformatics analysis in rats after traumatic spinal cord injury. Front Mol Neurosci 11: 497. doi:10.3389/fnmol.2018 .00497

Quan Z, Zheng D, Qing H. 2017. Regulatory roles of long noncoding RNAs in the central nervous system and associated neurodegenerative diseases. Front Cell Neurosci 11: 175. doi:10.3389/fncel.2017.00175

Ramos AD, Diaz A, Nellore A, Delgado RN, Park K-Y, Gonzales-Roybal G, Oldham MC, Song JS, Lim DA. 2013. Integration of genome-wide approaches identifies IncRNAs of adult neural stem cells and their progeny in vivo. Cell Stem Cell 12: 616-628. doi:10.1016/j.stem.2013.03.003
Ramos AD, Andersen RE, Liu SJ, Nowakowski TJ, Hong SJ, Gertz C, Salinas RD, Zarabi H, Kriegstein AR, Lim DA. 2015. The long noncoding RNA Pnky regulates neuronal differentiation of embryonic and postnatal neural stem cells. Cell Stem Cell 16: 439-447. doi:10.1016/j.stem.2015.02.007

Rani N, Nowakowski TJ, Zhou H, Godshalk SE, Lisi V, Kriegstein AR, Kosik KS. 2016. A primate lncRNA mediates notch signaling during neuronal development by sequestering miRNA. Neuron 90: 1174-1188. doi:10.1016/j.neuron.2016 .05 .005

Rapicavoli NA, Poth EM, Zhu H, Blackshaw S. 2011. The long noncoding RNA Six $3 O S$ acts in trans to regulate retinal development by modulating Six3 activity. Neural Dev 6: 32. doi:10 $.1186 / 1749-8104-6-32$

Ravasi T, Suzuki H, Pang KC, Katayama S, Furuno M, Okunishi R, Fukuda S, Ru K, Frith MC, Gongora MM, et al. 2006. Experimental validation of the regulated expression of large numbers of non-coding RNAs from the mouse genome. Genome Res 16: 11-19. doi:10.1101/gr.4200206

Ren Y, Cui Y, Li X, Wang B, Na L, Shi J, Wang L, Qiu L, Zhang $\mathrm{K}$, Liu G, et al. 2015. A co-expression network analysis reveals lncRNA abnormalities in peripheral blood in early-onset schizophrenia. Prog Neuropsychopharmacol Biol Psychiatry 63: 1 -5. doi:10.1016/j.pnpbp.2015.05.002

Riva P, Ratti A, Venturin M. 2016. The long non-coding RNAs in neurodegenerative diseases: novel mechanisms of pathogenesis. Curr Alzheimer Res 13: 1219-1231. doi:10.2174/ 1567205013666160622112234

Saijilafu, Hur E-M, Liu C-M, Jiao Z, Xu W-L, Zhou F-Q. 2013a. PI3K-GSK3 signalling regulates mammalian axon regeneration by inducing the expression of Smad1. Nat Commun 4: 2690. doi: $10.1038 /$ ncomms 3690

Saijilafu, Zhang B-Y, Zhou F-Q. 2013b. Signaling pathways that regulate axon regeneration. Neurosci Bull 29: 411-420. doi:10 $.1007 / \mathrm{s} 12264-013-1357-4$

Sauvageau M, Goff LA, Lodato S, Bonev B, Groff AF, Gerhardinger C, Sanchez-Gomez DB, Hacisuleyman E, Li E, Spence M, et al. 2013. Multiple knockout mouse models reveal lincRNAs are required for life and brain development. Elife 2: e01749. doi:10.7554/eLife.01749

Sekar S, Liang WS. 2019. Circular RNA expression and function in the brain. Noncoding RNA Res 4: 23-29. doi:10.1016/j .ncrna.2019.01.001

Singer RA, Arnes L, Cui Y, Wang J, Gao Y, Guney MA, BurnumJohnson KE, Rabadan R, Ansong C, Orr G, et al. 2019. The long noncoding RNA Paupar modulates PAX6 regulatory activities to promote $\alpha$ cell development and function. Cell Metab doi:10.1016/j.cmet.2019.09.013

Sone M, Hayashi T, Tarui H, Agata K, Takeichi M, Nakagawa S. 2007. The mRNA-like noncoding RNA Gomafu constitutes a novel nuclear domain in a subset of neurons. J Cell Sci 120: 2498-2506. doi:10.1242/jcs.009357

Sterne-Weiler T, Martinez-Nunez RT, Howard JM, Cvitovik I, Katzman S, Tariq MA, Pourmand N, Sanford JR. 2013. Frac-seq reveals isoform-specific recruitment to polyribosomes. Genome Res 23: 1615-1623. doi:10.1101/gr.148585 .112

Toy D, Namgung U. 2013. Role of glial cells in axonal regeneration. Exp Neurobiol 22: 68-76. doi:10.5607/en.2013.22.2.68

Tuck AC, Natarajan KN, Rice GM, Borawski J, Mohn F, Rankova A, Flemr M, Wenger A, Nutiu R, Teichmann S, et al. 2018. Distinctive features of lincRNA gene expression suggest widespread RNA-independent functions. Life Sci Alliance 1: e201800124. doi:10.26508/lsa.201800124

Ulitsky I. 2018. Interactions between short and long noncoding RNAs. FEBS Lett 592: 2874-2883. doi:10.1002/1873-3468 .13085

Ulitsky I, Shkumatava A, Jan CH, Sive H, Bartel DP. 2011. Conserved function of lincRNAs in vertebrate embryonic development despite rapid sequence evolution. Cell 147: 15371550. doi:10.1016/j.cell.2011.11.055

Vance KW, Sansom SN, Lee S, Chalei V, Kong L, Cooper SE, Oliver PL, Ponting CP. 2014. The long non-coding RNA Pau- 
par regulates the expression of both local and distal genes. EMBO J 33: 296-311. doi:10.1002/embj.201386225

Wan P, Su W, Zhuo Y. 2017. The role of long noncoding RNAs in neurodegenerative diseases. Mol Neurobiol 54: 2012-2021. doi:10.1007/s12035-016-9793-6

Wang C-F, Zhao C-C, Weng W-J, Lei J, Lin Y, Mao Q, Gao G-Y, Feng J-F, Jiang J-Y. 2017. Alteration in long non-coding RNA expression after traumatic brain injury in rats. $J$ Neurotrauma 34: 2100-2108. doi:10.1089/neu.2016.4642.

Wang H, Wu J, Zhang X, Ding L, Zeng Q. 2018. Microarray analysis of the expression profile of lncRNAs reveals the key role of lncRNA BC088327 as an agonist to heregulin-1 $\beta$-induced cell proliferation in peripheral nerve injury. Int $J \mathrm{Mol}$ Med 41: 3477-3484. doi:10.3892/ijmm.2018.3571.

Yan W, Chen Z-Y, Chen J-Q, Chen H-M. 2018. LncRNA NEAT1 promotes autophagy in MPTP-induced Parkinson's disease through stabilizing PINK1 protein. Biochem Biophys Res Commun 496: 1019-1024. doi:10.1016/j.bbrc.2017.12.149

Yang B, Xia Z-A, Zhong B, Xiong X, Sheng C, Wang Y, Gong W, Cao Y, Wang Z, Peng W. 2017. Distinct hippocampal expression profiles of long non-coding RNAs in an Alzheimer's disease model. Mol Neurobiol 54: 4833-4846. doi:10.1007/ s12035-016-0038-5.

Yao C, Yu B. 2019. Role of long noncoding RNAs and circular RNAs in nerve regeneration. Front Mol Neurosci 12: 165. doi:10.3389/fnmol.2019.00165

Yao C, Wang J, Zhang H, Zhou S, Qian T, Ding F, Gu X, Yu B. 2015. Long non-coding RNA uc.217 regulates neurite outgrowth in dorsal root ganglion neurons following peripheral nerve injury. Eur J Neurosci 42: 1718-1725. doi:10.1111/ejn .12966

Yao C, Wang Y, Zhang H, Feng W, Wang Q, Shen D, Qian T, Liu F, Mao S, Gu X, et al. 2018. IncRNA TNXA-PS1 modulates Schwann cells by functioning as a competing endogenous RNA following nerve injury. J Neurosci 38: 6574-6585. doi:10.1523/JNEUROSCI.3790-16.2018

Yen Y-P, Hsieh W-F, Tsai Y-Y, Lu Y-L, Liau ES, Hsu H-C, Chen Y-C, Liu T-C, Chang M, Li J, et al. 2018. Dlk1-Dio3 locusderived lncRNAs perpetuate postmitotic motor neuron cell fate and subtype identity. Elife 7: e38080. doi:10.7554/eLife .38080 .
Yi M, Dai X, Li Q, Xu X, Chen Y, Wang D. 2019. Downregulated IncRNA CRNDE contributes to the enhancement of nerve repair after traumatic brain injury in rats. Cell Cycle 18: 2332-2343. doi:10.1080/15384101.2019.1647024

Yu B, Zhou S, Hu W, Qian T, Gao R, Ding G, Ding F, Gu X. 2013. Altered long noncoding RNA expressions in dorsal root ganglion after rat sciatic nerve injury. Neurosci Lett 534: 117-122. doi:10.1016/j.neulet.2012.12.014

Zappulo A, van den Bruck D, Ciolli Mattioli C, Franke V, Imami K, McShane E, Moreno-Estelles M, Calviello L, Filipchyk A, Peguero-Sanchez E, et al. 2017. RNA localization is a key determinant of neurite-enriched proteome. Nat Commun 8: 583. doi:10.1038/s41467-017-00690-6

Zhang L, Wang H. 2019. Long non-coding RNA in CNS injuries: a new target for therapeutic intervention. Mol Ther Nucleic Acids 17: 754-766. doi:10.1016/j.omtn.2019.07.013

Zhang H, Li D, Zhang Y, Li J, Ma S, Zhang J, Xiong Y, Wang W, Li N, Xia L. 2018a. Knockdown of IncRNA BDNF-AS suppresses neuronal cell apoptosis via downregulating miR-130b$5 \mathrm{p}$ target gene PRDM5 in acute spinal cord injury. RNA Biol 15: 1071-1080. doi:10.1080/15476286.2017.1408764

Zhang H, Wang W, Li N, Li P, Liu M, Pan J, Wang D, Li J, Xiong Y, Xia L. 2018b. LncRNA DGCR5 suppresses neuronal apoptosis to improve acute spinal cord injury through targeting PRDM5. Cell Cycle 17: 1992-2000. doi:10.1080/15384101 .2018 .1509622

Zhao R-B, Zhu L-H, Shu J-P, Qiao L-X, Xia Z-K. 2018. GAS5 silencing protects against hypoxia/ischemia-induced neonatal brain injury. Biochem Biophys Res Commun 497: 285-291. doi:10.1016/j.bbrc.2018.02.070

Zhong J, Jiang L, Cheng C, Huang Z, Zhang H, Liu H, He J, Cao F, Peng J, Jiang Y, et al. 2016. Altered expression of long noncoding RNA and mRNA in mouse cortex after traumatic brain injury. Brain Res 1646: 589-600. doi:10.1016/j.brainres.2016 .07 .002

Zhou X, Xu J. 2015. Identification of Alzheimer's disease-associated long noncoding RNAs. Neurobiol Aging 36: 29252931. doi:10.1016/j.neurobiolaging.2015.07.015

Zhou Z-B, Du D, Chen K-Z, Deng L-F, Niu Y-L, Zhu L. 2019. Differential expression profiles and functional predication of circular ribonucleic acid in traumatic spinal cord injury of rats. J Neurotrauma 36: 2287-2297. doi:10.1089/neu.2018.6366 


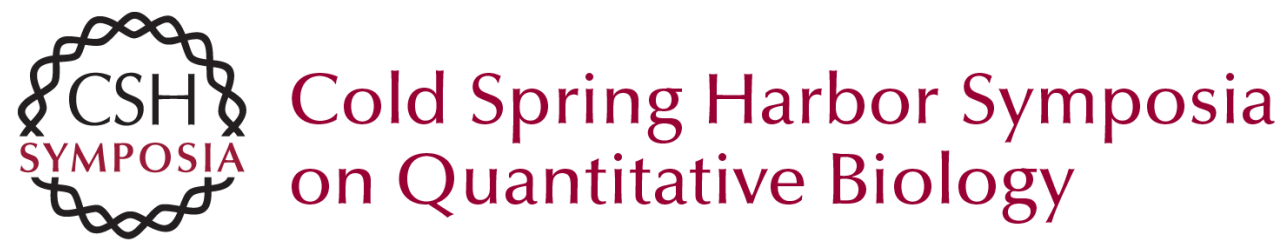

\section{Long Noncoding RNAs in Development and Regeneration of the Neural Lineage}

Hadas Hezroni, Rotem Ben Tov Perry and Igor Ulitsky

Cold Spring Harb Symp Quant Biol 2019 84: 165-177 originally published online January 3, 2020 Access the most recent version at doi:10.1101/sqb.2019.84.039347

References This article cites 101 articles, 13 of which can be accessed free at: http://symposium.cshlp.org/content/84/165.full.html\#ref-list-1

Creative This article is distributed under the terms of the

Commons http://creativecommons.org/licenses/by/4.0/, which permits unrestricted

License reuse and redistribution provided that the original author and source are credited.

Email Alerting Receive free email alerts when new articles cite this article - sign up in Service the box at the top right corner of the article or click here. 